Indexed by

\title{
Scopus
}

\section{INVESTIGATION THE EFFECTS OF GREEN MORTAR PARAMETERS USING ANALYTICAL METHODS}

Eethar Thanon Dawood

Northern Technical University,

Technical College of Mosul,

Building and Construction

Department, Mosul, Iraq

\section{Mafaz Hani Abdullah}

Northern Technical University,

Technical College of Mosul,

Building and Construction

Department, Mosul, Iraq

Key words: green mortar, environmental effects, regression analysis, AHP, TOPSIS doi:10.5937/jaes0-29726

Cite article:

Dawood Thanon E., Abdullah Hani M. (2021) INVESTIGATION THE EFFECTS OF GREEN MORTAR PARAMETERS USING ANALYTICAL METHODS, Journal of Applied Engineering Science, 19(4), 996 - 1012, DOI:10.5937/ jaes0-29726

Online aceess of full paper is available at: www.engineeringscience.rs/browse-issues 


\title{
INVESTIGATION THE EFFECTS OF GREEN MORTAR PARAMETERS USING ANALYTICAL METHODS
}

\author{
Eethar Thanon Dawood*, Mafaz Hani Abdullah \\ Northern Technical University, Technical College of Mosul, Building and Construction Department, Mosul, \\ Iraq
}

The various green mortar mixes have been used in this study using various percentages of waste glass powder (WGP), steel slag (SG) and Micro-silica fume(SF). The different properties of flow, density, ultrasonic pulse velocity (UPV), compressive and flexural strengths have been tested for such green mortar in the first phase of experimental work. The second phase deals with the regression analysis of such properties. Whereas, the analysis of the results have also been using the integrated AHP and TOPSIS methods for selection the best performance of the green mortar due to the ecological effects of such materials. The results showed that the use of $70 \% O P C+8 \% W G-$ $P+12 \% S G+10 \%$ SF indicated as the best performance in term of ecological impact compared with other mortar mixes. Also, the regression analysis using the integrated AHP and TOPSIS methods gives an effective strategy for the selection of the best mortar mix.

Key words: green mortar, environmental effects, regression analysis, AHP, TOPSIS

\section{INTRODUCTION}

Cement considers as most produced materials in the world. The annual global cement production ranges to 4.15 billion tons in 2016 , and is expected to increase to 4.25 billion tons per year in 2030 (1). The production of this material needs the use of a huge amount of raw materials, energy and fossil fuels in addition to air and water $(2,3,4)$. The pollutants generated and non-renewable resources consumed during cement industry make cement material has a negative impact on the environment (4). Although this industry causes the formation of wastewater, solid waste, and noise, the main environmental issues are associated with air emissions and energy consumption. The high amounts of the carbon dioxide $\left(\mathrm{CO}_{2}\right)$, nitrogen oxides ( $\mathrm{NO}, \mathrm{NO}_{2}, \mathrm{~N}_{2} \mathrm{O}$ ), sulfur oxides ( $\mathrm{SO} 2, \mathrm{SO} 3$ ) and dust emissions in addition to the other air pollutants are released from cement manufacturing $(5,6.7,8)$. Approximately $8 \%$ of global carbon dioxide $\left(\mathrm{CO}_{2}\right)$ emission is liberated from cement industry (8). Moreover, the production of one ton of cement releases 360 pounds of dust (9),requires about 1.597 metric ton of raw materials $(9,10)$ and consumes a high amounts of electricity and thermal energy. Another various industrial processes (silicon metal, ferrosilicon and steel) also have a significant role on the environment impact. The accumulation of solid wastes generated as a byproduct of these industry is one of the reasons which lead to deteriorate the environment. In 2016, the global crude steel, silicon and ferrosilicon production has estimated at 1630, 2.7 and 6.4 million tons respectively (11). Production of one ton of the steel, silicon and ferrosilicon generates a high amount of solid waste like slag and silica fume dust respectively (12). Besides the accumulation of the non-biodegradable solid waste like waste glass in the landfills is the one of phenomena which has negative impact on the environ- ment. For reducing this environmental impact, reducing of raw materials and energy consumption during cement production, producing sustainable building material, saving in cement and recycling of waste products, many materials were blended with cement to make green building materials (13-16). Waste glass powder (WGP), Steel slag (SG) and Silica fume (SF) are non-biodegradable materials and available as waste materials (17-19). Utilization these materials with cement can improve mortar flowability, early and long term strength and long term durability (20-22). Physical properties and chemical composition of these materials have a significant role on the properties of concrete. Many previous studies (2326) have concluded that the chemical composition and the particle size of WGP have governed its pozzolanic activity, smaller particles decrease alkali silica reaction and give higher strength.

Several researchers (22-35) have focused on the use of SG with cement to improve the density, durability and strength of concrete at later ages. Many researchers (28-32) have studied the properties of mortar or/and concrete prepared from blended cement with supplementary cementitious materials (SCMs).Silica fume is the one of SCMs which can contribute to improve the mechanical properties of mortar and concrete at identical water-binder ratio (W/b) and replacement level (33-35).

Several researchers have worked to improve accurate building material properties and predict new models.

Multiple regression analysis is the one of statistical techniques which have been utilized to analysis properties of concrete and mortar, predict the good relationship between concrete or mortar properties and produce generalized results for new concrete or mortar before test. Therefore, the objectives of this research are to study the 
multiple regression analysis for green mortar properties and to selecting the best green mortar based on its impact on the environment.

\section{MATERIALS AND MIX PROPORTIONS}

\section{Materials}

The physical and mechanical properties of Ordinary Portland Cement(OPC), waste glass powder (WGP) steel slag (SG) and silica fume (SF) are given in Table 1. The properties of superplasticizer are shown in Table 2. Tap water was utilized in all mixes. The sand used for preparing green mixes was prepared according to ASTM C778 (36). Superplasticizer was procured from Specialties construction chemicals factory, Jahra, Kuwait. Its commercial name is KUT PLAST PCE 600. It was used to enhance the workability of mixes.

\section{Mix proportions}

In this study, nineteen (19) mixes were prepared to produce green mortars, binder/sand ratio was 1:2.75, water + superplasticizer / binder ratio $(\mathrm{W}+\mathrm{SP} / \mathrm{B})$ was 0.39 , the mix proportions of these mixes are listed in Table 3.

\section{METHODOLOGY}

\section{Experimental method}

Flow test was conducted for each mix according to ASTM C1437 (37). Dry density test was conducted for $70.7 \times 70.7 \times 70.7 \mathrm{~mm}$ specimens at 28 day according to ASTM C642 (38). Ultrasonic pulse velocity (UPV) was performed through $70.7 \times 70.7 \times 70.7 \mathrm{~mm}$ specimens at 28 day as per to ASTM C597 (39) after thirty minutes of taking them out of water. The compressive and flexural strength tests were applied on $50 \times 50 \times 50 \mathrm{~mm}$ cubes and $40 \times 40 \times 160 \mathrm{~mm}$

Table 1: Physical properties and Chemical compositions of the OPC, WGP, SG and SF

\begin{tabular}{|c|c|c|c|c|}
\hline Description & OPC* $^{*}$ & WGP $^{* *}$ & $S G^{* *}$ & $\mathrm{SF}^{\star \star}$ \\
\hline \multicolumn{5}{|l|}{ Physical properties } \\
\hline Specific gravity, gm/cm ${ }^{3}$ & 3.15 & 2.315 & 4.994 & 1.98 \\
\hline Blaine's fineness, $\mathrm{cm}^{2} / \mathrm{gm}$ & 3560 & 4094 & 8028 & - \\
\hline \multicolumn{5}{|l|}{ Chemical composition (\% wt.) } \\
\hline Ferric oxide, $\mathrm{Fe}_{2} \mathrm{O}_{3} \%$ & 3.44 & 1.168 & 95.430 & 0.795 \\
\hline Calcium oxide, $\mathrm{CaO} \%$ & 61.46 & 11.940 & 0.646 & 1.436 \\
\hline Silicon dioxide, $\mathrm{SiO}_{2} \%$ & 19.53 & 72.71 & 4.027 & 93.29 \\
\hline Potassium oxide, $\mathrm{SO}_{3} \%$ & 2.25 & 0.323 & 0.837 & 0.851 \\
\hline Alkalies $\left(0.658 \mathrm{~K}_{2} \mathrm{O}+\mathrm{Na}_{2} \mathrm{O}\right) \%$ & 0.58 & 8.906 & 1.078 & 0.875 \\
\hline Manganese oxide, $\mathrm{MnO} \%$ & - & 0.014 & 0.496 & 0.043 \\
\hline Magnesium oxide, $\mathrm{MgO} \%$ & 3.82 & 1.480 & 0.141 & 0.137 \\
\hline Aluminum oxide, $\mathrm{Al}_{2} \mathrm{O}_{3} \%$ & 4.92 & 1.487 & 0.523 & 0.264 \\
\hline Loss of ignition, $\%$ & 3.11 & - & - & - \\
\hline $\mathrm{C}_{3} \mathrm{~S} \%$ & 57.39 & - & - & - \\
\hline $\mathrm{C}_{2} \mathrm{~S} \%$ & 13.53 & - & - & - \\
\hline $\mathrm{C}_{3} \mathrm{~A} \%$ & 7.20 & - & - & - \\
\hline $\mathrm{C}_{4} \mathrm{AF} \%$ & 10.46 & - & - & - \\
\hline \multicolumn{5}{|c|}{${ }^{*}$ Provided by the manufacturer of cement-Delta Cement Company-Sulaymania-Iraq } \\
\hline${ }^{* *}$ Tested by the authors & & & & \\
\hline
\end{tabular}

Table 2: Properties of superplasticizer

\begin{tabular}{|c|c|c|c|c|}
\hline \multicolumn{5}{|c|}{ Typical characteristics } \\
\hline Specific gravity & Setting time & Air entrainment & Chloride content & Calcium chloride Content \\
\hline $1.06-1.08 @ 20^{\circ} \mathrm{C}$ & $\begin{array}{c}\text { No retardation at } \\
\text { normal dosage }\end{array}$ & $\begin{array}{c}<1 \% \text { additional air is } \\
\text { entrained }\end{array}$ & Nil to Bs 5075 & Nil \\
\hline
\end{tabular}


prisms at different ages ( 7 and 28 days) by using ASTM C109 (40) and ASTM C348 (41) respectively.

\section{Collection of the estimated data resulting from industrials processes and computing of the amount of the resources consumed and pollutants generated from cement industry}

The estimated data of solid waste accumulated, the resources consumed and the emissions resulted from cement industry

Based on the evaluated data in 2016, the global cement production was reached to 4150 million tons (1). Raw materials such as Limestone, clay, Sand and iron ore are the main requirements for cement production and are consumed in the large quantity (42). According to previous studies $(9,10)$, the production of the one ton of cement requires about $1597 \mathrm{~kg}$ of raw materials. Therefor the global amount of raw materials consumed in 2016 were evaluated at 6628 million tons in this study. During cement manufacturing, the electricity and thermal energy are used in sufficient level. The thermal energy is used during cement processing while electricity energy is used for grinding of raw materials of cement and clinker $(43,44)$. The global amount of electricity energy and thermal energy consumed in 2016 was estimated at $91 \mathrm{KWh}$ and 3400 mega joules per one ton of cement and clinker produced respectively and the clinker to cement ratio was estimated at 0.66 (1). Furthermore, the global amount of thermal energy consumed per one ton of cement produced was calculated at 2244 mega joules in this research. Cement industry not only consumes non-renewable resources like raw materials, thermal energy and electricity energy but also releases air pollutants like $\mathrm{CO}_{2}$ and dust which have a negative impact on the environment and human health (79). About fifty percent $(50 \%)$ of Carbon dioxide $\left(\mathrm{CO}_{2}\right)$ released during cement industry is resulted from calcination process of limestone $\left(\mathrm{CaCO}_{3}\right)$ and another fifty percent $(50 \%)$ is resulted from fuel combustion in cement kilns (35). In 2016, the global amount of carbon dioxide $\left(\mathrm{CO}_{2}\right)$ emitted per one tone of cement produced was reached to $530 \mathrm{~kg}$ (1). Thus, the total amount of the global carbon dioxide $\left(\mathrm{CO}_{2}\right)$ emitted from the total amount of cement produced in the same year was estimated at 2200 million ton. In addition, the global amount of dust emitted during cement industry was also estimated at 676 million ton in this research based on the production of the one ton of cement releases approximately $163 \mathrm{Kg}$ of dust (9). Table 4. illustrated the summary of available data for production of one ton of cement in 2016.

On the other hand, the global amount of the crude steel,

Table 3: Mix proportions of green mortar

\begin{tabular}{|c|c|c|c|c|c|c|}
\hline Cement mixes (\%) & $\mathrm{OP}\left(\mathrm{Kg} / \mathrm{m}^{3}\right)$ & WGP $\left(\mathrm{Kg} / \mathrm{m}^{3}\right)$ & $\mathrm{SG}\left(\mathrm{Kg} / \mathrm{m}^{3}\right)$ & Sand $\left(\mathrm{Kg} / \mathrm{m}^{3}\right)$ & SP. $\left(\mathrm{L} / \mathrm{m}^{3}\right)$ & $\mathrm{W}+\mathrm{SP} . / \mathrm{B}$ \\
\hline $100 \% \mathrm{OPC}$ & 565 & 0 & 0 & 1554 & 2 & 0.39 \\
\hline $90 \%$ OPC $+10 \% W G P$ & 506 & 56 & 0 & 1546 & 2 & 0.39 \\
\hline $85 \% O P C+15 \% W G P$ & 476 & 84 & 0 & 1540 & 2 & 0.39 \\
\hline $80 \% O P C+20 \% W G P$ & 446 & 112 & 0 & 1535 & 1.7 & 0.39 \\
\hline $90 \% \mathrm{OPC}+10 \% \mathrm{SG}$ & 512 & 0 & 57 & 1565 & 2 & 0.39 \\
\hline $85 \% \mathrm{OPC}+15 \% \mathrm{SG}$ & 485 & 0 & 86 & 1570 & 2 & 0.39 \\
\hline $80 \% O P C+20 \% S G$ & 458 & 0 & 115 & 1576 & 2 & 0.39 \\
\hline $94 \% \mathrm{OPC}+6 \% \mathrm{SF}$ & 528 & 0 & 0 & 1546 & 2 & 0.39 \\
\hline $92 \% \mathrm{OPC}+8 \% \mathrm{SF}$ & 515 & 0 & 0 & 1540 & 2 & 0.39 \\
\hline $90 \% \mathrm{OPC}+10 \% \mathrm{SF}$ & 503 & 0 & 0 & 1537 & 2 & 0.39 \\
\hline $80 \% \mathrm{OPC}+8 \% \mathrm{WGP}+12 \% \mathrm{SG}$ & 454 & 45 & 68 & 1559 & 2 & 0.39 \\
\hline $80 \% O P C+10 \% W G P+10 \% S G$ & 452 & 45 & 68 & 1554 & 2 & 0.39 \\
\hline $80 \% \mathrm{OPC}+5 \% \mathrm{WGP}+15 \% \mathrm{SG}$ & 455 & 29 & 85 & 1565 & 2 & 0.39 \\
\hline $78 \% \mathrm{OPC}+10 \% \mathrm{WGP}+12 \% \mathrm{SG}$ & 441 & 57 & 68 & 1557 & 2 & 0.39 \\
\hline $75 \% \mathrm{OPC}+12.5 \% \mathrm{WGP}+12.5 \% \mathrm{SG}$ & 423 & 71 & 71 & 1554 & 2 & 0.39 \\
\hline $75 \% O P C+10 \% W G P+15 \% S G$ & 425 & 57 & 85 & 1559 & 2 & 0.39 \\
\hline $74 \% \mathrm{OPC}+8 \% \mathrm{WGP}+12 \% \mathrm{SG}+6 \% \mathrm{SF}$ & 417 & 45 & 68 & 1551 & 2 & 0.39 \\
\hline $72 \% \mathrm{OPC}+8 \% \mathrm{WGP}+12 \% \mathrm{SG}+8 \% \mathrm{SF}$ & 405 & 45 & 67 & 1546 & 2 & 0.39 \\
\hline $70 \% \mathrm{OPC}+8 \% W G P+12 \% S G+10 \% \mathrm{SF}$ & 393 & 45 & 67 & 1543 & 2 & 0.39 \\
\hline
\end{tabular}

Table 4: Summary of the evaluated data during the global cement production in 2016 (1, 9,43-44)

\begin{tabular}{|c|c|c|c|c|c|}
\hline $\begin{array}{c}\text { Production } \\
\text { one ton of } \\
\text { cement }\end{array}$ & $\begin{array}{c}\text { Raw materials } \\
\text { consumption }(\mathrm{Kg})\end{array}$ & $\begin{array}{c}\text { Electricity energy } \\
\text { consumption }(\mathrm{KWh})\end{array}$ & $\begin{array}{c}\text { Thermal energy } \\
\text { consumption }(\mathrm{Mj})\end{array}$ & $\begin{array}{c}\mathrm{CO}_{2} \text { emission } \\
(\mathrm{kg})\end{array}$ & $\begin{array}{c}\text { Dust emission } \\
(\mathrm{Kg})\end{array}$ \\
\cline { 2 - 6 } & 1597 & 91 & 2244 & 530 & 163 \\
\hline
\end{tabular}


silicon and ferrosilicon production had evaluated at 1630, 2.7 and 6.4 million tons respectively in 2016 (11). Approximately, $400 \mathrm{~kg}$ of steel slag, silica fume has produced as a byproduct per one ton of steel, silicone and ferrosilicon manufactured respectively (12) Therefore, the total amount of steel slag, silica fume in 2016 was estimated at 652, 3.64 million tons in this study. In addition, the global amount of the municipal solid waste was estimated to 2017 million tons in the same year (48). And the waste glass powder had formed about $5 \%$ of the municipal solid waste (48).

\section{The calculation of the amount of the resources consumed and air contaminants resulting from cement used in the preparation of the traditional mortar and non-reinforced green mortars}

The quantity of non-renewable resources (raw materials, electricity and thermal energy) consumed and air pollutants (carbon dioxide and dust) emitted during cement industry was calculated in this study. The calculation was based on the amount of cement used for preparation of the traditional mortar and non-reinforced green mortars. The data in Table 5 was used in the calculation of the total quantities of raw materials, electricity energy, thermal energy, $\mathrm{CO}_{2}$ and dust resulting from cement used in the conventional mortar and non-reinforced green mortar. In order to reduce the amount of cement used in the preparation of mortars, the solid waste (waste glass, steel slag and silica fume) was used as partial replacement of cement as listed Table 5. This table illustrated the amount of resources consumed and air pollutants generated from cement used to prepare the conventional mortar and non-reinforced green mortar.

\section{RESULTS AND DISCUSSION}

The results for green mortar mixes are shown in Table 6 . The results showed that the acceptable ranges of strengths and other properties can also be obtained using $30 \%$ replacements of cement.

\section{Regression analysis}

For analysis of green mortar data, Multivariable linear regression analysis (MLRA) was employed. The purpose of this analysis is to explain the relationship between one dependent variable and two or more independent variables. The general MLRA equation was shown below:

$Y=C+b_{1} X_{a}+b_{2} X_{b}+\cdots+b_{n} X_{n} \pm e$

Table 5: Quantity of cement and solid waste used for preparing mortars

\begin{tabular}{|c|c|c|c|c|c|c|c|c|c|}
\hline \multirow{2}{*}{$\begin{array}{l}\text { Number } \\
\text { of mix }\end{array}$} & \multirow{2}{*}{$\begin{array}{l}\text { Cement } \\
\text { amount } \\
\left(\mathrm{Kg} / \mathrm{m}^{3}\right)\end{array}$} & \multicolumn{5}{|c|}{$\begin{array}{l}\text { Resource consumed and Air pollutants emitted per one } \\
\text { kilogram of cement }{ }^{*}\end{array}$} & \multicolumn{3}{|c|}{$\begin{array}{c}\text { Amount of Solid waste replaced } \\
\text { by cement }\end{array}$} \\
\hline & & $\begin{array}{c}\text { Raw } \\
\text { materials } \\
\left(\mathrm{Kg} / \mathrm{m}^{3}\right)\end{array}$ & \begin{tabular}{|c} 
Electricity \\
energy \\
(KWh)
\end{tabular} & $\begin{array}{l}\text { Thermal } \\
\text { energy } \\
\text { (Mj) }\end{array}$ & $\begin{array}{c}\mathrm{CO}_{2} \\
\left(\mathrm{Kg} / \mathrm{m}^{3}\right)\end{array}$ & $\begin{array}{c}\text { Dust } \\
\left(\mathrm{Kg} / \mathrm{m}^{3}\right)\end{array}$ & $\begin{array}{c}\text { Waste } \\
\text { glass } \\
\left(\mathrm{Kg} / \mathrm{m}^{3}\right)\end{array}$ & $\begin{array}{c}\text { Steel } \\
\text { slag } \\
\left(\mathrm{Kg} / \mathrm{m}^{3}\right)\end{array}$ & $\begin{array}{c}\text { Silica } \\
\text { fume } \\
\left(\mathrm{Kg} / \mathrm{m}^{3}\right)\end{array}$ \\
\hline 1 & 565 & 902 & 51 & 1268 & 299 & 92 & 0 & 0 & 0 \\
\hline 2 & 506 & 808 & 46 & 1135 & 268 & 82 & 56 & 0 & 0 \\
\hline 3 & 476 & 760 & 43 & 1068 & 252 & 78 & 84 & 0 & 0 \\
\hline 4 & 446 & 712 & 41 & 1001 & 236 & 73 & 112 & 0 & 0 \\
\hline 5 & 512 & 818 & 47 & 1149 & 271 & 83 & 0 & 57 & 0 \\
\hline 6 & 485 & 775 & 44 & 1088 & 257 & 79 & 0 & 86 & 0 \\
\hline 7 & 458 & 731 & 42 & 1028 & 243 & 75 & 0 & 115 & 0 \\
\hline 8 & 528 & 843 & 48 & 1185 & 280 & 86 & 0 & 0 & 34 \\
\hline 9 & 515 & 822 & 47 & 1156 & 273 & 84 & 0 & 0 & 45 \\
\hline 10 & 503 & 803 & 46 & 1129 & 267 & 82 & 0 & 0 & 56 \\
\hline 11 & 454 & 725 & 41 & 1019 & 241 & 74 & 45 & 68 & 0 \\
\hline 12 & 452 & 722 & 41 & 1014 & 240 & 74 & 45 & 68 & 0 \\
\hline 13 & 455 & 727 & 41 & 1021 & 241 & 74 & 29 & 85 & 0 \\
\hline 14 & 441 & 704 & 40 & 990 & 234 & 72 & 57 & 68 & 0 \\
\hline 15 & 423 & 676 & 38 & 949 & 224 & 69 & 71 & 71 & 0 \\
\hline 16 & 425 & 679 & 39 & 954 & 225 & 69 & 57 & 85 & 0 \\
\hline 17 & 417 & 666 & 38 & 936 & 221 & 68 & 45 & 68 & 34 \\
\hline 18 & 405 & 647 & 37 & 909 & 215 & 66 & 45 & 67 & 45 \\
\hline 19 & 393 & 628 & 36 & 882 & 208 & 64 & 45 & 67 & 56 \\
\hline
\end{tabular}


Table 6: Green mortar test results

\begin{tabular}{|c|c|c|c|c|c|c|}
\hline \multirow{2}{*}{$\begin{array}{c}\text { Mix } \\
\text { No. }\end{array}$} & Cement mixes (\%) & \multirow{2}{*}{ Flow $(\%)$} & $\begin{array}{c}\text { Compres- } \\
\text { sive strength } \\
(\mathrm{MPa})\end{array}$ & $\begin{array}{c}\text { Flexural } \\
\text { strength } \\
(\mathrm{MPa})\end{array}$ & $\begin{array}{c}\text { UPV. } \\
(\mathrm{Km} / \\
\text { sec })\end{array}$ & $\begin{array}{c}\text { Dry density } \\
\left(\mathrm{Kg} / \mathrm{m}^{3}\right)\end{array}$ \\
\cline { 4 - 7 } & & & 28 day & 28 day & 28 day & 28 day \\
\hline 1 & $100 \%$ OPC & 113 & 40.331 & 7.823 & 4.521 & 2266 \\
\hline 2 & $90 \%$ OPC+10\%WGP & 113 & 31.722 & 6.782 & 4.046 & 2210 \\
\hline 3 & $85 \%$ OPC+15\%WGP & 115 & 40.017 & 7.800 & 4.402 & 2256 \\
\hline 4 & $80 \% O P C+20 \% W G P$ & 109 & 36.340 & 7.497 & 4.287 & 2250 \\
\hline 5 & $90 \% O P C+10 \% S G$ & 113 & 31.080 & 6.691 & 4.001 & 2212 \\
\hline 6 & $85 \% O P C+15 \% S G$ & 110 & 33.016 & 7.142 & 4.131 & 2242 \\
\hline 7 & $80 \% O P C+20 \% S G$ & 105 & 26.610 & 6.209 & 3.527 & 2165 \\
\hline 8 & $94 \% O P C+6 \% S F$ & 105 & 42.836 & 7.482 & 4.556 & 2270 \\
\hline 9 & $92 \% O P C+8 \% S F$ & 100 & 43.394 & 7.563 & 4.582 & 2283 \\
\hline 10 & $90 \% O P C+10 \% S F$ & 82 & 48.866 & 8.032 & 4.713 & 2369 \\
\hline 11 & $80 \% O P C+8 \% W G P+12 \% S G$ & 108 & 31.896 & 6.679 & 4.024 & 2220 \\
\hline 12 & $80 \% O P C+10 \% W G P+10 \% S G$ & 115 & 33.927 & 7.380 & 4.356 & 2248 \\
\hline 13 & $80 \% O P C+5 \% W G P+15 \% S G$ & 105 & 32.344 & 6.977 & 4.207 & 2229 \\
\hline 14 & $78 \% O P C+10 \% W G P+12 \% S G$ & 110 & 31.908 & 6.782 & 4.092 & 2222 \\
\hline 15 & $75 \% O P C+12.5 \% W G P+12.5 \% S G$ & 113 & 32.569 & 7.146 & 4.227 & 2235 \\
\hline 16 & $75 \% O P C+10 \% W G P+15 \% S G$ & 109 & 30.331 & 6.094 & 4.032 & 2206 \\
\hline 17 & $74 \% O P C+8 \% W G+12 \% S G+6 \% S F$ & 113 & 29.323 & 6.502 & 3.901 & 2197 \\
\hline 18 & $72 \% O P C+8 \% W G+12 \% S G+8 \% S F$ & 110 & 30.088 & 6.821 & 4.021 & 2210 \\
\hline 19 & $70 \% O P C+8 \% W G P+12 \% S G+10 \% S F$ & 108 & 32.068 & 7.321 & 4.107 & 2225 \\
\hline
\end{tabular}

Where, $Y$ is dependent variable; $C$ is constant; $b_{1}, b_{2}$ and $b_{n}$ are slopes associated with $X_{a}, X_{b}$ and $X_{n}$ respectively. $X_{a}, X_{b}$ and $X_{n}$ are independent variables and $e$ is error. For prediction of the strength of the green mortar before preparation it, the strength was considered as dependent variable, while the proportion of WGP, SG, SF, SIF, HHF, SNF, UPV, Density and curing time were considered as independent variables in this study. The enter techniques in SPSS program were used to create the regression models. The data analysis was done using MLRA. The number of important statistical parameters were associated with the MLRA. Some of these parameters were coefficient of regression determination, model error, the significance level, the confidence level, the t-distribution and the F-distribution. Detailed explanations of these important parameters can be found in previous studies (81). As a final approach; regression models were created to predict the strength of green mortars. The statistical parameters of regression models were calculated at the $95 \%$ confidence level. Summary of regression models were shown in Table 7. Predictive models of the strength of green mortar were given below:

$C S=35.033-(0.056 \times W G P)-(0.116 \times S G)-(0.042 \times S F)+(0.235 \times$ Age $) \quad$ Model 1

$C S=-174.051+(8.276 \times U P V)+(0.078 \times D S) \quad$ Model 2

$C S=-169.385-(0.021 \times W G P)-(0.052 \times S G)+(0.093 \times D S)$ Model 3
$C S=-25.892+(9.361 \times F S)-(0.208 \times A g e) \quad$ Model 4 $C S=36.257-(0.358 \times W G P)-(0.701 \times S G)+(0.235 \times$ Age $)$ Model 5 $F S=6.335-(0.002 \times W G P)-(0.011 \times S G)+(0.003 \times S F)+(0.047 \times A g e) \quad$ Model 6 $F S=3.393+(0.085 \times C S)+(0.027 \times$ Age $) \quad$ Model 7

$F S=-17.243+(0.011 \times D S)$ Model 8

Where, CS and FS is compressive strength ( $\mathrm{MPa}$ ) and flexural strength $(\mathrm{MPa})$ of green mortar respectively, $U P V$ and $D S$ is the ultrasonic pulse velocity $(\mathrm{km} / \mathrm{sec})$ and density of green mortar respectively, WGP is the content of waste glass powder (\%), SG is the content of steel slag (\%), SF is the content of silica fume (\%).

To assess the validity of the predictive models mentioned above; the behavior of correlation $(\mathrm{R})$, determination of coefficient (R2), the t-test, the F-test and Multicollinearity-test were considered. The statistical parameters of regression models of green mortar were shown in Table 7. The correlation coefficient( $R$ ) for all predictive models of non-reinforced and reinforced green mortar appear to lie in acceptable range. The value of determination coefficient (R2) of all regression models (1-8) for non-reinforced green mortar was $0.813,0.921,0.958,0.813$, $0.792,0.810,0.885$ and 0.725 respectively. And, for reinforced green mortars, the value of determination coefficient (R2) of all regression models (1-6) was 0.952 , $0.952,0.965,0.866,0.824$ and 0.819 respectively. A high 
Table 7: Regression models of green mortar (at the 95\% confidence level)

\begin{tabular}{|c|c|c|c|c|c|c|c|c|c|c|c|c|}
\hline \multirow{2}{*}{$\begin{array}{c}\text { Model } \\
\text { No. }\end{array}$} & \multirow{2}{*}{$\begin{array}{c}\text { Depen- } \\
\text { dent } \\
\text { variable }\end{array}$} & \multirow{2}{*}{$\begin{array}{c}\text { Independent } \\
\text { variable }\end{array}$} & \multirow{2}{*}{$\begin{array}{l}\text { Coeffi- } \\
\text { cient }\end{array}$} & \multirow{2}{*}{ t-value } & \multirow{2}{*}{$\begin{array}{l}\text { t-sig- } \\
\text { nifi- } \\
\text { cant }\end{array}$} & \multicolumn{2}{|c|}{$\begin{array}{c}\text { Determination } \\
\text { coefficient }\end{array}$} & \multirow{2}{*}{$\begin{array}{l}\text { Model } \\
\text { error }\end{array}$} & \multirow{2}{*}{ F-value } & \multirow{2}{*}{$\begin{array}{c}\text { F-sig- } \\
\text { nifi- } \\
\text { cant }\end{array}$} & \multicolumn{2}{|c|}{$\begin{array}{l}\text { Collinearity } \\
\text { statistics }\end{array}$} \\
\hline & & & & & & $\mathrm{R}$ & $\mathrm{R}^{2}$ & & & & $\begin{array}{l}\text { Toler- } \\
\text { ance }\end{array}$ & VIF \\
\hline \multirow{5}{*}{1} & \multirow{5}{*}{ CS } & Constant & 35.033 & 24.516 & 0.000 & \multirow{5}{*}{0.897} & \multirow{5}{*}{0.805} & \multirow{5}{*}{2.968} & \multirow{5}{*}{34.110} & \multirow{5}{*}{0.000} & - & - \\
\hline & & WGP & -0.056 & -3.617 & 0.001 & & & & & & 0.903 & 1.108 \\
\hline & & SG & -0.116 & -8.806 & 0.000 & & & & & & 0.923 & 1.084 \\
\hline & & SF & -0.042 & 1.742 & 0.091 & & & & & & 0.853 & 1.172 \\
\hline & & Age & 0.235 & 5.130 & 0.000 & & & & & & 1.000 & 1.000 \\
\hline \multirow{3}{*}{2} & \multirow{3}{*}{ CS } & Constant & -174.051 & -4.422 & 0.000 & \multirow{3}{*}{0.960} & \multirow{3}{*}{0.921} & \multirow{3}{*}{1.719} & \multirow{3}{*}{93.158} & \multirow{3}{*}{0.000} & - & - \\
\hline & & Density & 0.078 & 3.315 & 0.004 & & & & & & 0.164 & 6.085 \\
\hline & & UPV & 8.276 & 2.337 & 0.033 & & & & & & 0.164 & 6.085 \\
\hline \multirow{5}{*}{3} & \multirow{5}{*}{ CS } & Constant & -169.385 & -6.768 & 0.000 & & & & & & - & - \\
\hline & & WGP & -0.021 & -2.028 & 0.062 & & & & & & 0.834 & 1.199 \\
\hline & & SG & -0.052 & -4.616 & 0.000 & 0.979 & 0.959 & 1.330 & 81.059 & 0.000 & 0.509 & 1.965 \\
\hline & & SF & -0.001 & -0.034 & 0.973 & & & & & & 0.785 & 1.275 \\
\hline & & Density & 0.093 & 8.418 & 0.000 & & & & & & 0.447 & 2.239 \\
\hline & & Constant & -25.892 & -5.430 & 0.000 & & & & & & - & - \\
\hline 4 & CS & FS & 9.361 & 11.514 & 0.000 & 0.907 & 0.813 & 2.742 & 81.627 & 0.000 & 0.549 & 1.823 \\
\hline & & Age & -0.208 & -3.634 & 0.001 & & & & & & 0.549 & 1.823 \\
\hline & & Constant & 36.257 & 28.464 & 0.000 & & & & & & - & - \\
\hline$\Gamma$ & & WGP & -0.358 & -4.261 & 0.000 & & & & & & 0.996 & 1.004 \\
\hline 5 & CS & SG & -0.701 & -9.535 & 0.000 & 0.890 & 0.192 & 3.017 & 43.221 & 0.000 & 0.996 & 1.004 \\
\hline & & Age & 0.235 & 5.032 & 0.000 & & & & & & 1.000 & 1.000 \\
\hline & & Constant & 6.335 & 37.615 & 0.000 & & & & & & - & - \\
\hline & & WGP & -0.002 & -1.248 & 0.221 & & & & & & 0.903 & 1.108 \\
\hline 6 & FS & SG & -0.011 & -7.074 & 0.000 & 0.897 & 0.805 & 0.350 & 34.082 & 0.000 & 0.923 & 1.084 \\
\hline & & SF & 0.003 & 0.901 & 0.374 & & & & & & 0.853 & 1.172 \\
\hline & & Age & 0.047 & 8.743 & 0.000 & & & & & & 1.000 & 1.000 \\
\hline & & Constant & 3.393 & 15.284 & 0.000 & & & & & & - & - \\
\hline 7 & FS & CS & 0.085 & 11.514 & 0.000 & 0.941 & 0.885 & 0.260 & 135.230 & 0.000 & 0.845 & 1.183 \\
\hline & & Age & 0.027 & 6.267 & 0.000 & & & & & & 0.845 & 1.183 \\
\hline 8 & ES & Constant & -17.243 & -4.744 & 0.000 & 0852 & 0725 & 0294 & 44845 & 足 & - & - \\
\hline 0 & ro & Density & 0.0110 & 6.697 & 0.000 & 0.052 & $0.1<0$ & 0.294 & 44.045 & 0.000 & 1.000 & 1.000 \\
\hline
\end{tabular}

value for the correlation coefficient of predictive model does not necessarily to express the good performance of model (49). The value of determination coefficient (R2) does not establish the validity of predictive model unless the results of test for significance of regression, t-test and Multicollinearity-test show the consistency between the experimental results and predictive model. Therefore, test for significance of regression, t-test and Multicollinearity-test were considered.

Test for significance of regression was carried out using analysis of variance (F-test).This test was helped to determine whether the regression line was the most suitable curve in representing the relationship between the sample data sets of two correlated variables (48). The null hypothesis was designated $\mathrm{Ho}=0$, which means that no correlation exists between the two variables tested using analysis of variance. The analysis of variance produced two values for each model: an F-value, which indicates the degree to which the regression equation fits the data, and a second value that indicates the statistical significance of the F-value. In the case that the statistical significance of the F-value was less than 0.05 at the $95 \%$ confidence level, $\mathrm{Ho}=0$ was refused, meaning that the relationship between depended variable and the target independent variable could be expressed as a linear or non-linear equation at the $95 \%$ confidence level (49). 
Otherwise, it was assumed that the relationship could not be represented as a regression model (50). Therefore, all the predictive models in Table 7 are considered to be valid due to the significance of the F-value was less than 0.05 for all these models.

The t-test was used to examine the significance of the variables in each model at the $95 \%$ confidence level. By considering the degrees of freedom for each variable, a t-value calculated for the experimental data can be compared with a tabulated t-value. In case that the calculated $t$-value is greater than the tabulated value, the significance of $\mathrm{t}$-values was less than 0.05 at the $95 \%$ confidence level and the variable is considered to be significant to the model (50). The t-significance value of all predictive models for green mortars (except Model 1, 3 and 6 ) was less than 0.05 at the $95 \%$ confidence level. Therefore, Models-2, Model-4, Model-5, Model-7 and Model-8 of green mortars are considered to be valid. For green mortars; Model-1, SF exceeds 0.05 (0.091). For Model-3, WGP and SF exceed 0.05, The t-significance value was 0.062 and 0.973 respectively. For Model-6, WGP and SF exceed 0.05, The t-significance value was 0.221 and 0.374 respectively. Based on the obtained $\mathrm{t}$-significance values, all the regression models of green mortar are valid except for Models 1, 3 and 6 in Table 7.

Multicollinearity is a statistical phenomenon in which there exists a perfect or exact relationship between the predictor variables. In the other words, it means two or more of the independent variables in a multiple regression model are highly correlated $(25,34)$. This causes a problem in the interpretation of the regression results. Multicollinearity was tested using Tolerance $(T)$ and the variance inflation factor (VIF). Tolerance is the amount of variability in one independent variable that is no explained by the other independent variables $(56,63)$. Tolerance values less than 0.10 indicate to the presence of multicollinearity. The variance inflation factor (VIF)is defined as the inverse of Tolerance $(1 / T)$. In case that the (VIF) is more than 5 , the multicollinearity has been presented. Tolerance values of all predictive models of green mortars were more than 0.1 .

The variance inflation factors (VIF) of all predictive models in Table 7 were less than 5, except Model-2 of green mortar. For this model, the variance inflation factor of UPV and Density was 6.085 and 6.085 respectively. Therefore, Model-2 of green mortar was considered invalid because of multicollinearity problems.

\section{AHP and TOPSIS methodology}

\section{Analytic Hierarchy Process (AHP)}

The Analytic Hierarchy Process (AHP) is a multi-criteria decision making approach which organizes and analyzes complex decisions (50). It was developed by Thomas Saaty in the 1970, 1980 and 1990 (51). The decision problem in this approach is arranged in hierarchic structure (51). The arrangement is in the descending form from an overall goal to criteria, sub-criteria and alternatives in successive levels (52). In this paper, AHP was used to evaluate the weight of the thirteen (13) criteria of reinforced green mortars and non-reinforced green mortars. Five (5) of them were compressive strength, Flexural strength, UPV and Cost of reinforced green mortars and another eight (8) were Raw materials, Electricity energy, Thermal energy, $\mathrm{CO}_{2}$, Dust, Waste glass, Steel slag and Silica fume of green mortars. The criteria weights of green mortars were computed using the following general steps:

Step 1: Conduct the comparison for two criteria at the same time with respect their impact on the mortar prepared. The comparison conducts based on the one common scale (adapted from Satty) that is displayed in Table 8. to build the Pair-wise comparison matrix $(F)$.

The Pair-wise comparison matrix $(F)$ builds by asking questions to experts or decision makers like, which criterion is more important with regards to the decision goal. The answers to these questions will construct the matrix (F) as shown below:

$$
\left.F=\begin{array}{c}
C_{1} \\
C_{1} \\
C_{2} \\
\vdots \\
C_{m}
\end{array} \begin{array}{cccc}
f_{11} & f_{12} & \cdots & f_{1 m} \\
f_{21} & f_{22} & \cdots & f_{2 m} \\
\vdots & \vdots & \vdots & \vdots \\
f_{m 1} & f_{m 2} & \cdots & f_{m m}
\end{array}\right\}=(f i j)_{m \times m}
$$

where fij represents a quantified judgment on $\mathrm{Ci} / \mathrm{Cj}$ with fii $=1$ and $\mathrm{fij}=1 / \mathrm{fji}$ for $\mathrm{i}, \mathrm{j}=1, \ldots, \mathrm{m}$

Step 2: Compute the sum $\sum_{i=1}^{4}$ fij for each column in matrix $(F)$. Then, divide (Fij) to computed sum according to Eq.1, the result will be matrix $(X)$ :

$x i j=\frac{F i j}{\sum_{i=1}^{m} F i j}(i=1,2 . .4, j=1,2 . .4)$

Table 8: One common scale (adapted from Saaty) used in this study

\begin{tabular}{|l|c|c|c|c|c|c|}
\hline & \multicolumn{5}{|c|}{ Definition } \\
\hline & $\begin{array}{c}\text { Equal } \\
\text { importance }\end{array}$ & $\begin{array}{c}\text { Somewhat more } \\
\text { important }\end{array}$ & $\begin{array}{c}\text { Much more } \\
\text { important }\end{array}$ & $\begin{array}{c}\text { Very much more } \\
\text { important }\end{array}$ & $\begin{array}{c}\text { Absolutely } \\
\text { more } \\
\text { important }\end{array}$ & $\begin{array}{c}\text { Intermedi- } \\
\text { ate Values }\end{array}$ \\
\hline Intensity of importance & 1 & 3 & 5 & 7 & 9 & $2,4,6,8$ \\
\hline
\end{tabular}




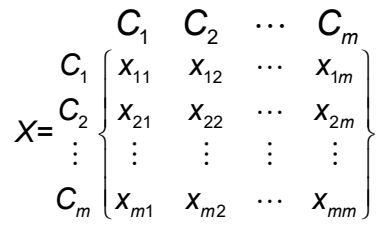

Step 3: Calculate the average of each raw in the matrix $(\mathrm{X})$ to obtain the weight $(w)$ of each criterion.

Step 4: Check the consistency of the pairwise comparison matrix (F) by using the following steps:

a. Construct matrix $(\mathrm{Y})$ by multiplying the criterion weight $(w)$ with pairwise comparison matrix $(F)$.

$$
\begin{array}{cccc}
C_{1} & C_{2} & \cdots & C_{m}
\end{array}
$$

$C_{1}\left(\begin{array}{llll}Y_{11} & Y_{12} & \cdots & Y_{1 m}\end{array}\right)$

$\left.Y=\begin{array}{c}C_{2} \\ \vdots \\ C_{m}\end{array} \begin{array}{cccc}Y_{21} & Y_{22} & \cdots & Y_{2 n} \\ \vdots & \vdots & \vdots & \vdots \\ Y_{m 1} & Y_{m 2} & \cdots & Y_{m n}\end{array}\right\}$

Where Yij represents the result of the multiplying fij by wj, $\mathrm{i}=1, \ldots, \mathrm{m} ; \mathrm{j}=1, \ldots, \mathrm{m}$.

b. Calculate the sum of each raw $\left(\sum_{j=1}^{4} Y i j\right)$ in the matrix $(Y)$. The result will be $(S)$.

$$
S=\left\{\begin{array}{c}
S_{1} \\
S_{2} \\
\vdots \\
S_{m}
\end{array}\right\}
$$

c. Divide the calculated sum of each raw $(S)$ o criterion weight (wi). The result will be (S/W)

$S / W=\left\{\begin{array}{c}S_{1} / W_{1} \\ S_{2} / W_{2} \\ \vdots \\ S_{m} / w_{m}\end{array}\right\}$

d. Compute the consistency index $(\mathrm{Cl})$ according to Eq. 2.

$C l=\frac{\left(\frac{\sum_{i=1}^{m}(S / w) i j}{m}\right)-m}{m-1}$ (where, $m$ is number of compared criteria)

The random consistency index $(\mathrm{RCl})$ is obtained using Table 9 (Saaty (52)). Based on the number of the criteria used in AHP method, the random consistency index is determined. The consistency ratio $(\mathrm{CR})$ is computed by dividing $(\mathrm{Cl})$ to $(\mathrm{RC})$. If the consistency ratio $(\mathrm{CR})$ is $\leq 0.1$,the pair wise comparison matrix $(F)$ is considered to have an acceptable trust worthy and consistency; otherwise, it required to be revised (53).

\section{Technique for Order Performance by Similarity to Ideal Solution (TOPSIS)}

TOPSIS is a simple and useful approach which is used to deal with the complex system related to making a best choice among several alternatives (54). It was developed by Ching-Lai Hwang and Yoon in 1981. The concept of this technique is based on the selecting the ideal alternative which has the shortest distance from the positive ideal solution and the farthest distance from the negative ideal solution (55). In this research, TOPSIS was used to select and rank the best of reinforced green mortar based on its properties. In addition this technique was also used to determine and rank the best and worst non-reinforced green mortar based on its impact on the environment. The ranking and determining of reinforced and non-reinforced green mortars was achieved using the following steps:

Step 1: Construct the decision matrix $(\mathrm{N})$ for ranking of the alternatives, the structure of matrix can be expressed as follow:

$N=\begin{gathered}C_{1} \\ A_{1} \\ A_{2} \\ \vdots \\ A_{m}\end{gathered}\left\{\begin{array}{cccc}Z_{11} & Z_{12} & \cdots & Z_{1 n} \\ Z_{21} & Z_{22} & \cdots & Z_{2 n} \\ \vdots & \vdots & \vdots & \vdots \\ Z_{m 1} & Z_{m 2} & \cdots & Z_{m n}\end{array}\right\}$

where Ai represents the alternatives $\mathrm{i}, \mathrm{i}=1 \ldots . ., \mathrm{m}$; $\mathrm{Cj}$ represents the criteria that are required on which the alternative is judged, $j=1 \ldots, n$; Zij represents jth attribute, $j=1$, $n$ related to $i$, the alternative; and $Z \mathrm{ij}$ is the obtained value representing the performance rating of each alternative $\mathrm{Ai}$ with respect to each requirement $\mathrm{Cj}$.

Step 2: Calculate the normalized decision matrix (V): The raw data can be normalized by utilizing Eq. 3. to produce the matrix $(\mathrm{V})$.

$V i j=\frac{n i f}{\sqrt{\sum_{i=1}^{m} n i^{2}}}$ where $\mathrm{i}=1,2,3, \ldots, \mathrm{m}$ and $\mathrm{j}=1,2,3, \ldots, \mathrm{n}$

Step 3: Compute the weighted normalized decision matrix (B) by multiplying the weights of criteria $(w)$ with the normalized decision matrix $(\mathrm{V})$. In this paper, the weights of criteria (w) were previously calculated based on AHP method.

Step 4: determine the positive ideal reference point $(A+)$ and negative ideal reference point (A-) respectively.

$A^{+}=\left\{a_{1}{ }^{+}, a_{2}{ }^{+} \ldots . . a_{n}{ }^{+}\right\}=\{(\max$ bij $\mid j \in C b),(\operatorname{mini} b i j \mid j \in C P)\}$ $A^{-}=\left\{a_{1}{ }^{-}, a_{2}{ }^{-} \ldots \ldots a_{n}{ }^{-}\right\}=\{(\operatorname{mini}$ bij $\mid j \in C b),(\max$ bij $\mid j \in C P)\}$ where $C b$ is benefit-type attributes (the higher value is the better) and $C p$ is benefit -type attribute (the lower

Table 9: Values of the Random Consistency Index (RCI) for small problems

\begin{tabular}{|c|c|c|c|c|c|c|c|c|c|}
\hline \multicolumn{10}{|c|}{ Number of criteria } \\
\hline & 2 & 3 & 4 & 5 & 6 & 7 & 8 & 9 & 10 \\
\hline Random Consistency Index & 0 & 0.58 & 0.90 & 1.12 & 1.24 & 1.32 & 1.41 & 1.45 & 1.51 \\
\hline
\end{tabular}


value is the better).

Step 5: Compute the distance of all alternatives to the positive and negative ideal reference point (D+ and $D-)$ by using Eq. 4 and Eq.5 respectively.

$D i^{+}=\sqrt{\sum_{j=1}^{n}\left(b i j-a j^{+}\right)^{2}}$

$D i^{-}=\sqrt{\sum_{j=1}^{n}\left(b i j-a j^{-}\right)^{2}}$

Step 6: Calculate the relative closeness coefficient $(R)$ of each alternative to the ideal reference point by using Eq. 4. Then, conduct the outranking of the alternatives in descending order. The larger value of $R i$ indicates to the better performance of the alternative.

$R i=\frac{D i-}{(D i+)+(D i-)}$

\section{Performance of the regression models to predict strength parameters}

The strength of green mortar can be predicted using regression models. For prediction the strength of such green mortar, it is possible to use Model-4, Model-5, Model-7 and Model-8 in Table 10. The comparison between the obtained strength from the experimental results and regression models was illustrated in Fig. 1. The statistical parameters of valid regression models are shown in Table 10.

Table 10: Performance of the predicted models

\begin{tabular}{|c|c|c|c|c|c|}
\hline 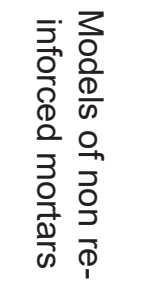 & & $\begin{array}{l}\frac{3}{\mathbb{D}} \\
\stackrel{0}{J}\end{array}$ & 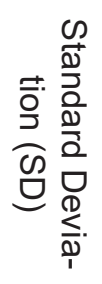 & 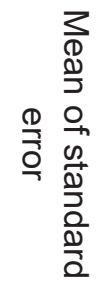 & 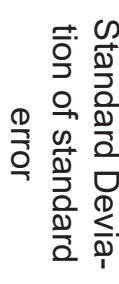 \\
\hline Model-4 & CS & 32.196 & 5.763 & 0.761 & 0.129 \\
\hline Model-5 & CS & 32.196 & 5.646 & 0.968 & 0.187 \\
\hline Model-7 & FS & 6.594 & 0.704 & 0.072 & 0.015 \\
\hline Model-8 & FS & 7.091 & 0.463 & 0.088 & 0.036 \\
\hline
\end{tabular}

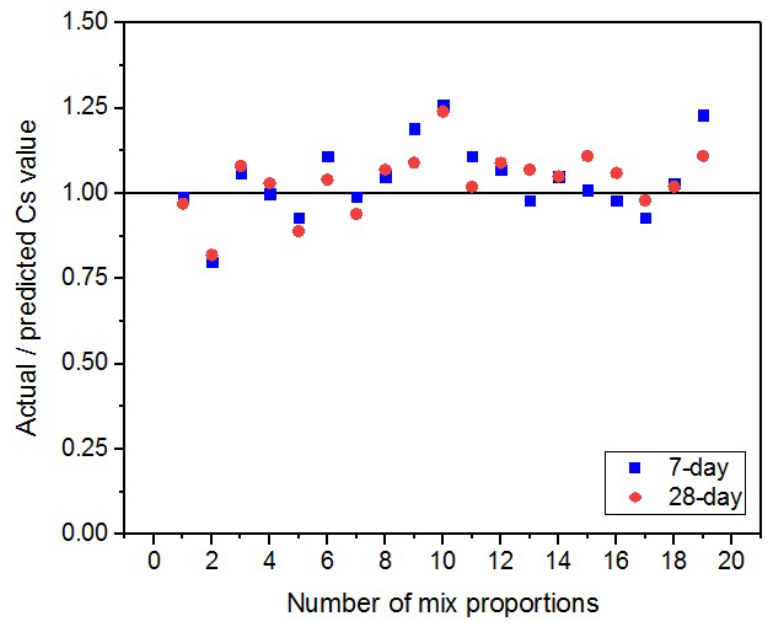

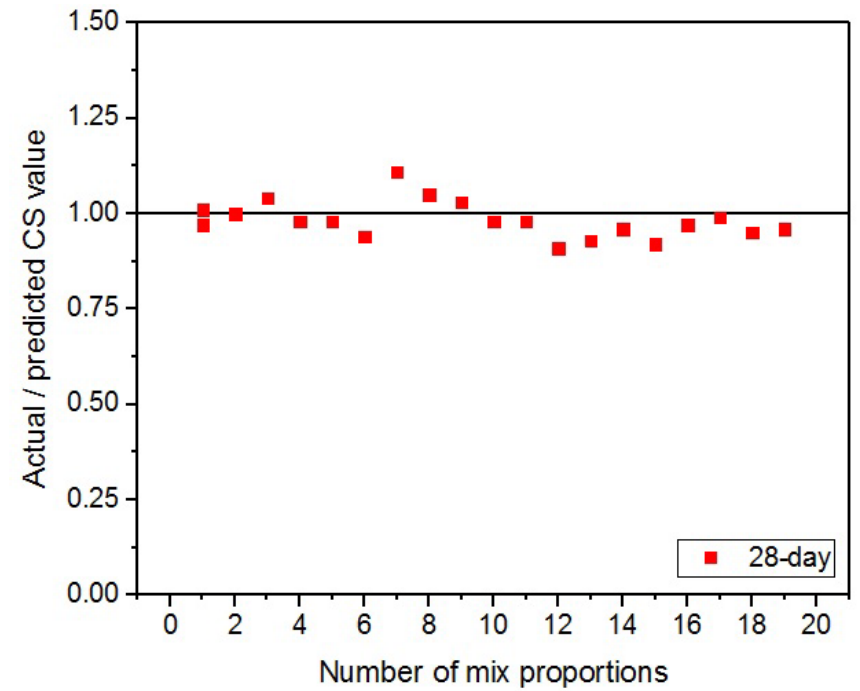
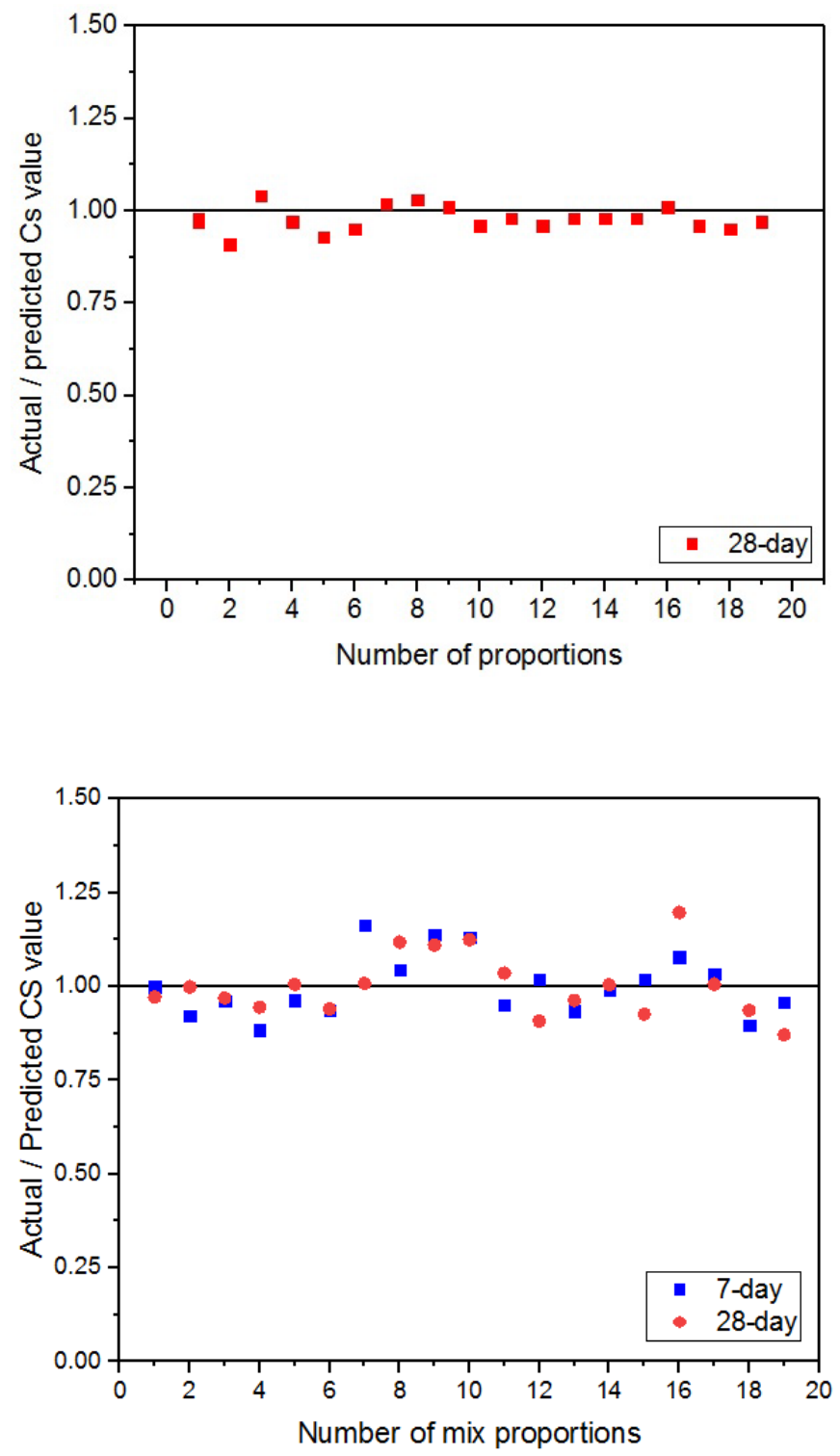

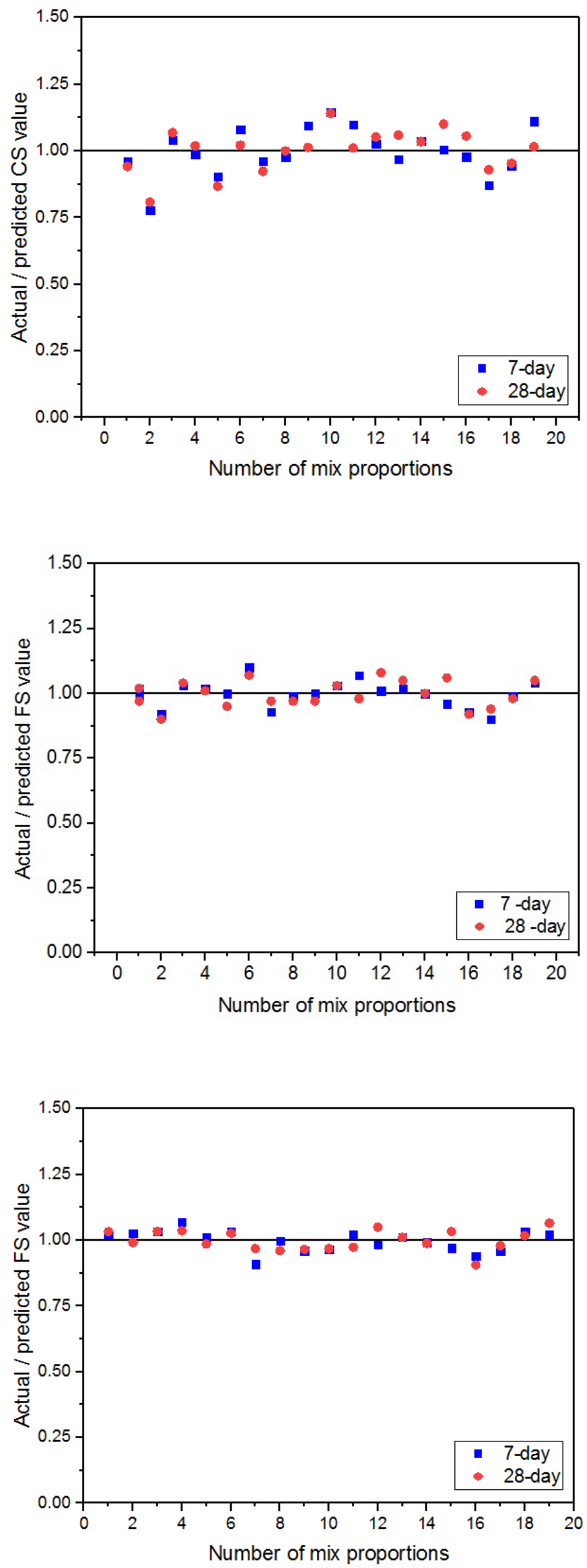

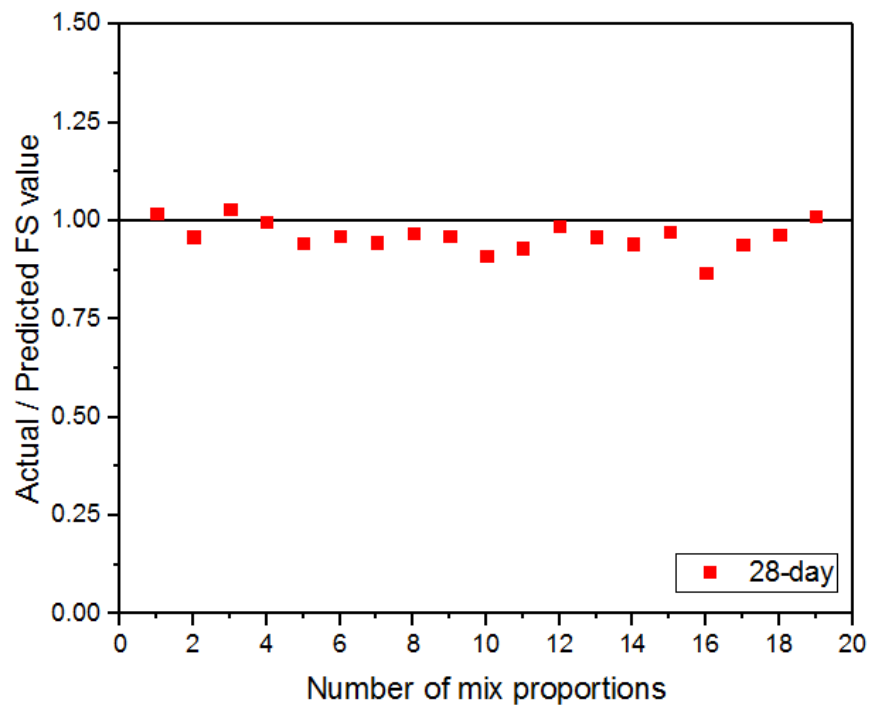

Figure 1: Comparison of strength parameters predict for green mortars

\section{Impact assessment of the traditional mortar and green mortars on the environment}

In order to assess the impact of the traditional mortar (it has not contained a partial replacement of cement) and green mortar on the environment, the integrated AHP and TOPSIS method was used. Based on the non-renewable resource consumed, air pollutants emitted during cement industry and the solid waste used as replacement of cement, the environmental impact of mortars was assessed in this study. The non-renewable resources consumed were raw materials, electricity energy and thermal energy required cement industry. Air pollutants were carbon dioxide and dust emitted during cement production. The solid wastes used as a partial replacement of cement were: waste glass, steel slag and silica fume. Therefore the eight criteria were considered. The evaluated weight of each criterion based on AHP method was listed in Table 11. In order to check the pair-wise comparison matrix, that was shown in Table 12. According to AHP method, the weight of these criteria (Raw materials, electricity energy, Thermal energy, CO2, Dust, Waste glass, Steel slag, and silica fume) was computed. The matrices, that are obtained through applying of AHP method, were shown in Table 13., the step 4 that was mentioned previously in the general steps of AHP method, was applied as shown in Table 14. Therefore, the calculated consistency index was 0.082041 and the random consistency index obtained from Table 15 was 1.41. Consequently, the consistency ratio was 0.058 . Due the consistency ratio was below 0.1 , the pair-wise comparison matrix was considered. Then, the general steps of TOPSIS technique were applied to rank and select the best of the green mortar based on its impact on the environment. The raw data considered in TOPSIS technique were listed in Table 16. The matrices and results obtained through this technique were shown in Table 16-21.

Table 21 and Fig. 2 have shown that the $19^{\text {th }}$ mix of green mortar is the best as it got the rank 1 and the first mix is the worst mix as it got the rank 19. 
Table 11: The criteria weights evaluated by AHP method

\begin{tabular}{|c|c|c|c|c|c|c|c|c|}
\hline \multicolumn{10}{|c|}{ Criteria } \\
\hline & Raw materials & $\begin{array}{c}\text { Electricity } \\
\text { energy }\end{array}$ & $\begin{array}{c}\text { Thermal } \\
\text { energy }\end{array}$ & $\mathrm{CO}_{2}$ & Dust & $\begin{array}{c}\text { Waste } \\
\text { glass }\end{array}$ & Steel slag & $\begin{array}{c}\text { Silica } \\
\text { fume }\end{array}$ \\
\hline Weight & 0.17 & 0.08 & 0.13 & 0.13 & 0.09 & 0.12 & 0.20 & 0.08 \\
\hline
\end{tabular}

Table 12: The pair-wise comparison matrix $(F)$ of green mortars criteria

\begin{tabular}{|c|c|c|c|c|c|c|c|c|}
\hline & $\begin{array}{c}\text { Raw mate- } \\
\text { rials }\end{array}$ & $\begin{array}{c}\text { Electricity } \\
\text { energy }\end{array}$ & $\begin{array}{c}\text { Thermal } \\
\text { energy }\end{array}$ & $\mathrm{CO}_{2}$ & Dust & Waste glass & Steel slag & $\begin{array}{c}\text { Silica } \\
\text { fume }\end{array}$ \\
\hline Raw materials & 1 & 2 & 1 & 1 & 1 & 2 & 2 & 2 \\
\hline Electricity energy & $1 / 2$ & 1 & $1 / 2$ & $1 / 2$ & 1 & $1 / 2$ & $1 / 2$ & 2 \\
\hline Thermal energy & 1 & 2 & 1 & 1 & 2 & 1 & 0.5 & 1 \\
\hline $\mathrm{CO}_{2}$ & 1 & 2 & 1 & 1 & 2 & 2 & $1 / 3$ & 1 \\
\hline Dust & 1 & 1 & $1 / 2$ & $1 / 2$ & 1 & 1 & $1 / 3$ & 1 \\
\hline Waste glass & $1 / 2$ & 2 & 1 & $1 / 2$ & 1 & 1 & $1 / 2$ & 3 \\
\hline Steel slag & $1 / 2$ & 2 & 2 & 3 & 3 & 2 & 1 & 2 \\
\hline Silica fume & $1 / 2$ & $1 / 2$ & 1 & 1 & 1 & $1 / 3$ & $1 / 2$ & 1 \\
\hline
\end{tabular}

Table 13: Matrix $X$ obtained from AHP method for green mortars criteria

\begin{tabular}{|c|c|c|c|c|c|c|c|c|}
\hline & $\begin{array}{c}\text { Raw } \\
\text { materials }\end{array}$ & $\begin{array}{c}\text { Electrici- } \\
\text { ty energy }\end{array}$ & $\begin{array}{c}\text { Thermal } \\
\text { energy }\end{array}$ & $\mathrm{CO}_{2}$ & Dust & Waste glass & Steel slag & $\begin{array}{c}\text { Silica } \\
\text { fume }\end{array}$ \\
\hline Raw materials & 0.166667 & 0.16 & 0.125 & 0.117647 & 0.083333 & 0.20339 & 0.352941 & 0.153846 \\
\hline $\begin{array}{c}\text { Electricity } \\
\text { energy }\end{array}$ & 0.083333 & 0.08 & 0.0625 & 0.058824 & 0.083333 & 0.050847 & 0.088235 & 0.153846 \\
\hline $\begin{array}{c}\text { Thermal } \\
\text { energy }\end{array}$ & 0.166667 & 0.16 & 0.125 & 0.117647 & 0.166667 & 0.101695 & 0.088235 & 0.076923 \\
\hline $\mathrm{CO}_{2}$ & 0.166667 & 0.16 & 0.125 & 0.117647 & 0.166667 & 0.20339 & 0.058824 & 0.076923 \\
\hline Dust & 0.166667 & 0.08 & 0.0625 & 0.058824 & 0.083333 & 0.101695 & 0.058824 & 0.076923 \\
\hline Waste glass & 0.083333 & 0.16 & 0.125 & 0.058824 & 0.083333 & 0.101695 & 0.088235 & 0.230769 \\
\hline Steel slag & 0.083333 & 0.16 & 0.25 & 0.352941 & 0.25 & 0.20339 & 0.176471 & 0.153846 \\
\hline Silica fume & 0.083333 & 0.04 & 0.125 & 0.117647 & 0.083333 & 0.033898 & 0.088235 & 0.076923 \\
\hline
\end{tabular}

Table 14: Matrix Y for checking the pair-wise comparison matrix evaluated in AHP method

\begin{tabular}{|c|c|c|c|c|c|c|c|c|c|c|}
\hline & $\begin{array}{c}\text { Raw } \\
\text { materi- } \\
\text { als }\end{array}$ & $\begin{array}{c}\text { Elec- } \\
\text { tricity } \\
\text { energy }\end{array}$ & $\begin{array}{c}\text { Thermal } \\
\text { energy }\end{array}$ & $\mathrm{CO}_{2}$ & Dust & $\begin{array}{c}\text { Waste } \\
\text { glass }\end{array}$ & Steel slag & $\begin{array}{c}\text { Silica } \\
\text { fume }\end{array}$ & Si & Si/wi \\
\hline $\begin{array}{c}\text { Raw ma- } \\
\text { terials }\end{array}$ & 0.17 & 0.16 & 0.13 & 0.13 & 0.09 & 0.24 & 0.4 & 0.16 & 1.48 & 8.705882 \\
\hline $\begin{array}{c}\text { Electricity } \\
\text { energy }\end{array}$ & 0.085 & 0.08 & 0.065 & 0.065 & 0.09 & 0.06 & 0.1 & 0.16 & 0.705 & 8.812500 \\
\hline $\begin{array}{c}\text { Thermal } \\
\text { energy }\end{array}$ & 0.17 & 0.16 & 0.13 & 0.13 & 0.18 & 0.12 & 0.1 & 0.08 & 1.07 & 8.230769 \\
\hline $\mathrm{CO}_{2}$ & 0.17 & 0.16 & 0.13 & 0.13 & 0.18 & 0.24 & 0.066667 & 0.08 & 1.156667 & 8.897438 \\
\hline Dust & 0.17 & 0.08 & 0.065 & 0.065 & 0.09 & 0.12 & 0.066667 & 0.08 & 0.736667 & 8.185189 \\
\hline $\begin{array}{c}\text { Waste } \\
\text { glass }\end{array}$ & 0.085 & 0.16 & 0.13 & 0.065 & 0.09 & 0.12 & 0.1 & 0.24 & 0.99 & 8.250000 \\
\hline Steel slag & 0.085 & 0.16 & 0.26 & 0.39 & 0.27 & 0.24 & 0.2 & 0.16 & 1.765 & 8.825000 \\
\hline $\begin{array}{c}\text { Silica } \\
\text { fume }\end{array}$ & 0.085 & 0.04 & 0.13 & 0.13 & 0.09 & 0.04 & 0.1 & 0.08 & 0.695 & 8.687500 \\
\hline
\end{tabular}


Table 15: Values of the Random Consistency Index (RCI) for small problems

\begin{tabular}{|c|c|c|c|c|c|c|c|c|c|}
\hline \multicolumn{10}{|c|}{ Number of criteria } \\
\hline & 2 & 3 & 4 & 5 & 6 & 7 & 8 & 9 & 10 \\
\hline Random Consistency Index & 0 & 0.58 & 0.90 & 1.12 & 1.24 & 1.32 & 1.41 & 1.45 & 1.51 \\
\hline
\end{tabular}

Table 16: The alternatives and criteria used in TOPSIS method

\begin{tabular}{|c|c|c|c|c|c|c|c|c|}
\hline $\begin{array}{c}\text { Number of } \\
\text { mix }\end{array}$ & $\begin{array}{c}\text { Raw materi- } \\
\text { als }\left(\mathrm{Kg} / \mathrm{m}^{3}\right)\end{array}$ & $\begin{array}{c}\text { Electricty En- } \\
\text { ergy (KWh) }\end{array}$ & $\begin{array}{c}\text { Thermal } \\
\text { energy }(\mathrm{Mj})\end{array}$ & $\mathrm{CO}_{2}\left(\mathrm{Kg} / \mathrm{m}^{3}\right)$ & $\begin{array}{c}\text { Dust } \\
\left(\mathrm{Kg} / \mathrm{m}^{3}\right)\end{array}$ & $\begin{array}{c}\text { Waste glass } \\
\left(\mathrm{Kg} / \mathrm{m}^{3}\right)\end{array}$ & $\begin{array}{c}\text { Steel slag } \\
\left(\mathrm{Kg} / \mathrm{m}^{3}\right)\end{array}$ & $\begin{array}{c}\text { Silica fume } \\
\left(\mathrm{Kg} / \mathrm{m}^{3}\right)\end{array}$ \\
\hline 1 & 902 & 51 & 1268 & 299 & 92 & 0 & 0 & 0 \\
\hline 2 & 808 & 46 & 1135 & 268 & 82 & 56 & 0 & 0 \\
\hline 3 & 760 & 43 & 1068 & 252 & 78 & 84 & 0 & 0 \\
\hline 4 & 712 & 41 & 1001 & 236 & 73 & 112 & 0 & 0 \\
\hline 5 & 818 & 47 & 1149 & 271 & 83 & 0 & 57 & 0 \\
\hline 6 & 775 & 44 & 1088 & 257 & 79 & 0 & 86 & 0 \\
\hline 7 & 731 & 42 & 1028 & 243 & 75 & 0 & 115 & 0 \\
\hline 8 & 843 & 48 & 1185 & 280 & 86 & 0 & 0 & 34 \\
\hline 9 & 822 & 47 & 1156 & 273 & 84 & 0 & 0 & 45 \\
\hline 10 & 803 & 46 & 1129 & 267 & 82 & 0 & 0 & 56 \\
\hline 11 & 725 & 41 & 1019 & 241 & 74 & 45 & 68 & 0 \\
\hline 12 & 722 & 41 & 1014 & 240 & 74 & 45 & 68 & 0 \\
\hline 13 & 727 & 41 & 1021 & 241 & 74 & 29 & 85 & 0 \\
\hline 14 & 704 & 40 & 990 & 234 & 72 & 57 & 68 & 0 \\
\hline 15 & 676 & 38 & 949 & 224 & 69 & 71 & 71 & 0 \\
\hline 16 & 679 & 39 & 954 & 225 & 69 & 57 & 85 & 0 \\
\hline 17 & 666 & 38 & 936 & 221 & 68 & 45 & 68 & 34 \\
\hline 18 & 647 & 37 & 909 & 215 & 66 & 45 & 67 & 45 \\
\hline 19 & 628 & 36 & 882 & 208 & 64 & 45 & 67 & 56 \\
\hline
\end{tabular}

Table 17: Decision matrix (N) obtained from TOPSIS method for selection of the best alternative

\begin{tabular}{|c|c|c|c|c|c|c|c|c|}
\hline & Raw materials & Electricity energy & Thermal energy & $\mathrm{CO}_{2}$ & Dust & Waste glass & Steel slag & Silica fume \\
\hline $\mathrm{A}_{1}$ & 902 & 51 & 1268 & 299 & 92 & 0 & 0 & 0 \\
\hline $\mathrm{A}_{2}$ & 808 & 46 & 1135 & 268 & 82 & 56 & 0 & 0 \\
\hline $\mathrm{A}_{3}$ & 760 & 43 & 1068 & 252 & 78 & 84 & 0 & 0 \\
\hline $\mathrm{A}_{4}$ & 712 & 41 & 1001 & 236 & 73 & 112 & 0 & 0 \\
\hline $\mathrm{A}_{5}$ & 818 & 47 & 1149 & 271 & 83 & 0 & 57 & 0 \\
\hline $\mathrm{A}_{6}$ & 775 & 44 & 1088 & 257 & 79 & 0 & 86 & 0 \\
\hline $\mathrm{A}_{7}$ & 731 & 42 & 1028 & 243 & 75 & 0 & 115 & 0 \\
\hline $\mathrm{A}_{8}$ & 843 & 48 & 1185 & 280 & 86 & 0 & 0 & 34 \\
\hline $\mathrm{A}_{9}$ & 822 & 47 & 1156 & 273 & 84 & 0 & 0 & 45 \\
\hline $\mathrm{A}_{10}$ & 803 & 46 & 1129 & 267 & 82 & 0 & 0 & 56 \\
\hline $\mathrm{A}_{11}$ & 725 & 41 & 1019 & 241 & 74 & 45 & 68 & 0 \\
\hline $\mathrm{A}_{12}$ & 722 & 41 & 1014 & 240 & 74 & 45 & 68 & 0 \\
\hline $\mathrm{A}_{13}$ & 727 & 41 & 1021 & 241 & 74 & 29 & 85 & 0 \\
\hline $\mathrm{A}_{14}$ & 704 & 40 & 990 & 234 & 72 & 57 & 68 & 0 \\
\hline $\mathrm{A}_{15}$ & 676 & 38 & 949 & 224 & 69 & 71 & 71 & 0 \\
\hline $\mathrm{A}_{16}$ & 679 & 39 & 954 & 225 & 69 & 57 & 85 & 0 \\
\hline $\mathrm{A}_{17}$ & 666 & 38 & 936 & 221 & 68 & 45 & 68 & 34 \\
\hline $\mathrm{A}_{18}$ & 647 & 37 & 909 & 215 & 66 & 45 & 67 & 45 \\
\hline $\mathrm{A}_{19}$ & 628 & 36 & 882 & 208 & 64 & 45 & 67 & 56 \\
\hline
\end{tabular}


Table 18: Normalized decision matrix (V) obtained from TOPSIS method

\begin{tabular}{|c|c|c|c|c|c|c|c|c|}
\hline & Raw materials & Electricity energy & Thermal energy & $\mathrm{CO}_{2}$ & Dust & Waste glass & Steel slag & Silica fume \\
\hline $\mathrm{A}_{1}$ & 0.276631 & 0.274567 & 0.276735 & 0.276327 & 0.27646 & 0 & 0 & 0 \\
\hline $\mathrm{A}_{2}$ & 0.247803 & 0.247648 & 0.247708 & 0.247678 & 0.24641 & 0.263282 & 0 & 0 \\
\hline $\mathrm{A}_{3}$ & 0.233082 & 0.231498 & 0.233086 & 0.232891 & 0.23439 & 0.394924 & 0 & 0 \\
\hline $\mathrm{A}_{4}$ & 0.218361 & 0.22073 & 0.218464 & 0.218105 & 0.219365 & 0.526565 & 0 & 0 \\
\hline $\mathrm{A}_{5}$ & 0.25087 & 0.253032 & 0.250764 & 0.250451 & 0.249415 & 0 & 0.214166 & 0 \\
\hline $\mathrm{A}_{6}$ & 0.237682 & 0.236881 & 0.237451 & 0.237512 & 0.237395 & 0 & 0.323128 & 0 \\
\hline $\mathrm{A}_{7}$ & 0.224188 & 0.226114 & 0.224356 & 0.224574 & 0.225375 & 0 & 0.43209 & 0 \\
\hline $\mathrm{A}_{8}$ & 0.258537 & 0.258416 & 0.258621 & 0.258768 & 0.25843 & 0 & 0 & 0.302488 \\
\hline $\mathrm{A}_{9}$ & 0.252096 & 0.253032 & 0.252292 & 0.252299 & 0.25242 & 0 & 0 & 0.400352 \\
\hline $\mathrm{A}_{10}$ & 0.246269 & 0.247648 & 0.246399 & 0.246754 & 0.24641 & 0 & 0 & 0.498216 \\
\hline $\mathrm{A}_{11}$ & 0.222348 & 0.22073 & 0.222392 & 0.222725 & 0.22237 & 0.211566 & 0.255497 & 0 \\
\hline $\mathrm{A}_{12}$ & 0.221428 & 0.22073 & 0.221301 & 0.221801 & 0.22237 & 0.211566 & 0.255497 & 0 \\
\hline $\mathrm{A}_{13}$ & 0.222961 & 0.22073 & 0.222828 & 0.222725 & 0.22237 & 0.136343 & 0.319371 & 0 \\
\hline $\mathrm{A}_{14}$ & 0.215907 & 0.215347 & 0.216063 & 0.216256 & 0.21636 & 0.267984 & 0.255497 & 0 \\
\hline $\mathrm{A}_{15}$ & 0.20732 & 0.204579 & 0.207115 & 0.207015 & 0.207345 & 0.333805 & 0.266768 & 0 \\
\hline $\mathrm{A}_{16}$ & 0.20824 & 0.209963 & 0.208206 & 0.207939 & 0.207345 & 0.267984 & 0.319371 & 0 \\
\hline $\mathrm{A}_{17}$ & 0.204253 & 0.204579 & 0.204278 & 0.204242 & 0.20434 & 0.211566 & 0.255497 & 0.302488 \\
\hline $\mathrm{A}_{18}$ & 0.198426 & 0.199196 & 0.198385 & 0.198697 & 0.19833 & 0.211566 & 0.251739 & 0.400352 \\
\hline $\mathrm{A}_{19}$ & 0.192599 & 0.193812 & 0.192492 & 0.192228 & 0.19232 & 0.211566 & 0.251739 & 0.498216 \\
\hline
\end{tabular}

Table 19: The weighted normalized decision matrix $(B)$ obtained from TOPSIS method

\begin{tabular}{|c|c|c|c|c|c|c|c|c|}
\hline & Raw materials & Electricity energy & Thermal energy & $\mathrm{CO}_{2}$ & Dust & Waste glass & Steel slag & Silica fume \\
\hline $\mathrm{A}_{1}$ & 0.047027 & 0.021965 & 0.035976 & 0.035923 & 0.024881 & 0 & 0 & 0 \\
\hline $\mathrm{A}_{2}$ & 0.042126 & 0.019812 & 0.032202 & 0.032198 & 0.022177 & 0.031594 & 0 & 0 \\
\hline $\mathrm{A}_{3}$ & 0.039624 & 0.01852 & 0.030301 & 0.030276 & 0.021095 & 0.047391 & 0 & 0 \\
\hline $\mathrm{A}_{4}$ & 0.037121 & 0.017658 & 0.0284 & 0.028354 & 0.019743 & 0.063188 & 0 & 0 \\
\hline $\mathrm{A}_{5}$ & 0.042648 & 0.020243 & 0.032599 & 0.032559 & 0.022447 & 0 & 0.042833 & 0 \\
\hline $\mathrm{A}_{6}$ & 0.040406 & 0.01895 & 0.030869 & 0.030877 & 0.021366 & 0 & 0.064626 & 0 \\
\hline $\mathrm{A}_{7}$ & 0.038112 & 0.018089 & 0.029166 & 0.029195 & 0.020284 & 0 & 0.086418 & 0 \\
\hline $\mathrm{A}_{8}$ & 0.043951 & 0.020673 & 0.033621 & 0.03364 & 0.023259 & 0 & 0 & 0.024199 \\
\hline $\mathrm{A}_{9}$ & 0.042856 & 0.020243 & 0.032798 & 0.032799 & 0.022718 & 0 & 0 & 0.032028 \\
\hline $\mathrm{A}_{10}$ & 0.041866 & 0.019812 & 0.032032 & 0.032078 & 0.022177 & 0 & 0 & 0.039857 \\
\hline $\mathrm{A}_{11}$ & 0.037799 & 0.017658 & 0.028911 & 0.028954 & 0.020013 & 0.025388 & 0.051099 & 0 \\
\hline $\mathrm{A}_{12}$ & 0.037643 & 0.017658 & 0.028769 & 0.028834 & 0.020013 & 0.025388 & 0.051099 & 0 \\
\hline $\mathrm{A}_{13}$ & 0.037903 & 0.017658 & 0.028968 & 0.028954 & 0.020013 & 0.016361 & 0.063874 & 0 \\
\hline $\mathrm{A}_{14}$ & 0.036704 & 0.017228 & 0.028088 & 0.028113 & 0.019472 & 0.032158 & 0.051099 & 0 \\
\hline $\mathrm{A}_{15}$ & 0.035244 & 0.016366 & 0.026925 & 0.026912 & 0.018661 & 0.040057 & 0.053354 & 0 \\
\hline $\mathrm{A}_{16}$ & 0.035401 & 0.016797 & 0.027067 & 0.027032 & 0.018661 & 0.032158 & 0.063874 & 0 \\
\hline $\mathrm{A}_{17}$ & 0.034723 & 0.016366 & 0.026556 & 0.026551 & 0.018391 & 0.025388 & 0.051099 & 0.024199 \\
\hline $\mathrm{A}_{18}$ & 0.033732 & 0.015936 & 0.02579 & 0.025831 & 0.01785 & 0.025388 & 0.050348 & 0.032028 \\
\hline $\mathrm{A}_{19}$ & 0.032742 & 0.015505 & 0.025024 & 0.02499 & 0.017309 & 0.025388 & 0.050348 & 0.039857 \\
\hline
\end{tabular}

Table 20: The positive and negative ideal reference point for each criterion

\begin{tabular}{|c|c|c|c|c|c|c|c|c|}
\hline & Raw material & Electricity energy & Thermal energy & $\mathrm{CO}_{2}$ & Dust & Waste glass & Steel slag & Silica fume \\
\hline $\mathrm{a}_{\mathrm{i}}^{+}$ & 0.032742 & 0.015505 & 0.025024 & 0.02499 & 0.017309 & 0.063188 & 0.086418 & 0.039857 \\
\hline $\mathrm{a}_{\mathrm{i}}^{-}$ & 0.047027 & 0.021965 & 0.035976 & 0.035923 & 0.024881 & 0 & 0 & 0 \\
\hline
\end{tabular}


Table 21: The distance to the positive and negative ideal reference point (Di+ and Di), relative closeness coefficient (Ri) to the ideal reference point and the ranking for each alternative

\begin{tabular}{|c|c|c|c|c|c|}
\hline Number of mix & Alternative & $\mathrm{Di}^{+}$ & $\mathrm{Di}^{-}$ & $\mathrm{Ri}$ & Alternative Ranking \\
\hline 1 & $\mathrm{~A}_{1}$ & 0.116585 & 0 & 0 & 19 \\
\hline 2 & $\mathrm{~A}_{2}$ & 0.101433 & 0.032592 & 0.243179 & 16 \\
\hline 3 & $\mathrm{~A}_{3}$ & 0.097123 & 0.048898 & 0.33487 & 13 \\
\hline 4 & $\mathrm{~A}_{4}$ & 0.095442 & 0.065196 & 0.405857 & 12 \\
\hline 5 & $\mathrm{~A}_{5}$ & 0.087992 & 0.043422 & 0.330421 & 14 \\
\hline 6 & $\mathrm{~A}_{6}$ & 0.078817 & 0.065523 & 0.453949 & 11 \\
\hline 7 & $\mathrm{~A}_{7}$ & 0.075236 & 0.087609 & 0.53799 & 6 \\
\hline 8 & $\mathrm{~A}_{8}$ & 0.109738 & 0.024701 & 0.183734 & 18 \\
\hline 9 & $\mathrm{~A}_{9}$ & 0.108616 & 0.032722 & 0.231516 & 17 \\
\hline 10 & $\mathrm{~A}_{10}$ & 0.1081 & 0.040713 & 0.273585 & 15 \\
\hline 11 & $\mathrm{~A}_{11}$ & 0.065827 & 0.059005 & 0.472675 & 10 \\
\hline 12 & $\mathrm{~A}_{12}$ & 0.0658 & 0.059061 & 0.473014 & 9 \\
\hline 13 & $\mathrm{~A}_{13}$ & 0.066026 & 0.067607 & 0.505915 & 7 \\
\hline 14 & $\mathrm{~A}_{14}$ & 0.061979 & 0.062664 & 0.502748 & 8 \\
\hline 15 & $\mathrm{~A}_{15}$ & 0.05686 & 0.069449 & 0.549834 & 4 \\
\hline 16 & $\mathrm{~A}_{16}$ & 0.055485 & 0.07398 & 0.571429 & 2 \\
\hline 17 & $\mathrm{~A}_{17}$ & 0.054148 & 0.065136 & 0.546058 & 5 \\
\hline 18 & $\mathrm{~A}_{18}$ & 0.052858 & 0.068362 & 0.56395 & 3 \\
\hline 19 & $\mathrm{~A}_{19}$ & 0.052248 & 0.072874 & 0.582424 & 1 \\
\hline
\end{tabular}

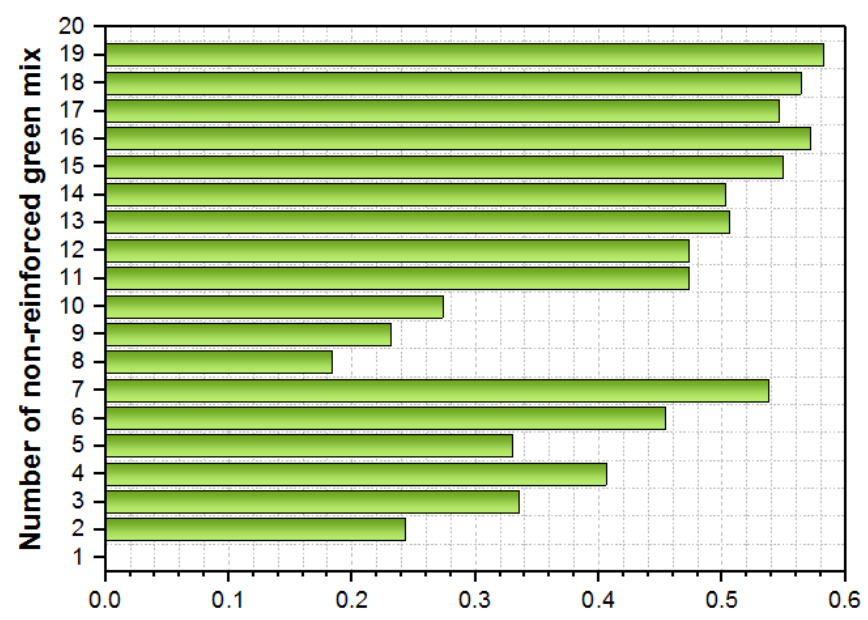

Relative closeness cofficient of non-reinforced green mix

Figure 2: Closeness coefficient of non-reinforced green mortars

\section{CONCLUSIONS}

The study shows very interesting analytical equations that indicate significant relationships between each of compressive and flexural strengths for green mortar with different parameters used in the production of green mortar mixes. Such parameters included the age of the mortar, density, UPV, SF, WGP, SG and SF. The statistical parameters of regression models were calculated at the $95 \%$ confidence level. Besides, based on integrated AHP and TOPSIS method have shown dramatic meth- ods or the selection of the most important mortar mix that exhibit the best performance in ecological effects. Thus, the mix M19 which contains $70 \%$ OPC+8\%WG$\mathrm{P}+12 \% \mathrm{SG}+10 \% \mathrm{SF}$ is classified as the best green mortar and the control mortar mix is the worst green mortar in terms of their impact on the environment.

\section{ACKNOWLEDGEMENTS}

This work was achieved in the laboratory of Mosul Technical College.

\section{REFERENCES}

1. IEA. (2019) "Cement-Tracking Industry," IEA, Paris, available at https://www.iea.org/reports/tracking-industry-2019.

2. Valderrama, C, Grandos, R., Cortina. J. L., Gasol, C. M., Guillem, M. , and Josa, A. (2012) "Implementation of Best Available Techniques in Cement Manufacturing: A Life-Cycle Assessment Study." Journal of Cleaner Production 25: 60-67.

3. Galvez-martos, J.I., and Schoenberger, H. (2014) "Resources ,Conservation and Recycling an Analysis of the Use of Life Cycle Assessment for Waste Co-Incineration in Cement Kilns." "Resources, Conservation \& Recycling" 86 : 118-31. https://doi. org/10.1016/j.resconrec.2014.02.009. 
4. Çankaya, S. and Pekey, B. (2019) "A Comparative Life Cycle Assessment for Sustainable Cement Production in Turkey." Journal of Environmental Management 249 (August): 109362. https://doi. org/10.1016/j.jenvman.2019.109362.

5. Worrell, E. (2013) "Energy Efficiency Improvement and Cost Saving Opportunities for Cement Making An ENERGY STAR $®$ Guide for Energy and Plant Manager"United states Environmental Protection Agency.

6. Mishra and Siddiqui (2014) "A Review On Environmental and Health Impacts Of Cement Manufacturing Emissions."International Journal of Geology, Agriculture and Environmental Sciences. www.woarjournals.org/IJGAES

7. Devi, K. S. (2018) "Impacts of Cement Industry on Environment - An Overview," Asia Pacific Journal of Research.

8. Andrew, R. M (2018) "Global $\mathrm{CO}_{2}$ Emissions from Cement Production," Earth System Science Data, 10, 195-217. https://doi.org/10.5194/essd-10-1952018

9. Babor, D. T, and Judele, L. (2014) "Environmental Impact of Concrete,"Bulletin of the Polytechnic Institute of Jassy, CONSTRUCTIONS. ARCHITECTURE Section.

10. Ali, N., Anwer, M. and Anjum, M.N. (2015) "The Greenhouse Gas Emissions Produced by Cement Production and Its Impact on Environment: A Review of Global Cement Processing" International Journal of Research ( IJR ). http://internationaljournalofresearch.org

11. RoskillInformation Services (2017)"Outlook for silicon metal diverges sharply from that for ferrosilicon," Roskill, united kingdom, available at https://roskill. com/news/outlook-silicon-metal-diverges-sharply-ferrosilicon.

12. Malhotra, K. (2019) "Iron and Steel Slag Utilization : A Comprehensive Analysis,"International Journal of Engineering Science Invention (IJESI) 8 (08): 69-74

13. Dave, N., Kumar, A., Srivastava, A., and Kumar,S. (2016) "Experimental Analysis of Strength and Durability Properties of Quaternary Cement Binder and Mortar." Construction and Building Materials 107: 117-24. https://doi.org/10.1016/j.conbuildmat.2015.12.195

14. Al-hubboubi, S. K, and Alwared, A.I.(2018) "Effect of Waste Glass Powder as a Supplementary Cementitious Material on the Concrete Mix Properties,". https://doi.org/10.13140/RG.2.2.21896.67845

15. Islam, I., Rahman and Das (2011) "Strength Behavior of Mortar Using Slag As Partial Replacement of Cement,"MIST Journal:GAIAXY(DHAKA). https:// doi.org/10.3329/mist.v3i0.8053
16. Khazaleh, M.( 2019) "Eco-Friendly Green Concrete : A Review,"IAPE '19, Oxford, United Kingdom: 19-21.

17. Muthupriya, P., Vishnuram, B G and Subramanian, K. (2008) "PREVENTION OF AIR POLLUTION BY USING SILICA FUME AS CEMENTITIOUS MATERIAL" Nature Environment and Pollution Technology 7 (2): 267-70.

18. Mines, M. O F, Indian Bureau, and Mines,O.F.( 2017) "SLAG - IRON AND STEEL" Indian MineralsYearbook 2016 (0712): 1-11.

19. Mehta, A., and Ashish, D. K.(2019) "Silica fume and waste glass in cement concrete production: $A$ review" Journal of Building Engineering. https://doi. org/10.1016/j.jobe.2019.100888

20. Ban, C. C. and Ramli,M. (2015) "Mechanical Strength and Durability Properties of High Performance Mortar Containing Densified Silica Fume," American Journal of Applied Sciences 8 (1): 82-91, 2011. https://doi.org/10.3844/ajassp.2011.82.91

21. Rashad, A.M.( 2014) "Recycled Waste Glass as Fine Aggregate Replacement in Cementitious Materials Based on Portland Cement." Construction and Building Materials 72: 340-57. https://doi.org/10.1016/j. conbuildmat.2014.08.092

22. Hussein, D. R.(2017) "STUDYING THE EFFECT OF IRAQI STEEL SLAG ADDITION ON THE PHYSICAL AND MECHANICAL PROPERTIES OFCEMENT MORTAR,"Journal of Engineering and Sustainable Development.21(3):2520-0917.

23. Shao, Y., Lefort,T., Moras,S., and Rodriguez,D. (2000) "Studies on Concrete Containing Ground Waste Glass"Cement and Concrete Research 30: 91-100.

24. Shi, C., and Zheng,K.(2007) "A Review on the Use of Waste Glasses in the Production of Cement and Concrete" Resources, Conservation and Recycling 52: 234-47. https://doi.org/10.1016/j.resconrec.2007.01.013.

25. Bignozzi, M C, Saccani,A., Barbieri,L. and Lancellotti,I. (2015) "Glass Waste as Supplementary Cementing Materials: The Effects of Glass Chemical Composition." CEMENT AND CONCRETE COMPOSITES 55: 45-52. https://doi.org/10.1016/j.cemconcomp.2014.07.020.

26. Kamali, M., and Ghahremaninezhad,A. (2016) "An Investigation into the Hydration and Microstructure of Cement Pastes Modified with Glass Powders." Construction and Building Materials 112: 915-24. https://doi.org/10.1016/j.conbuildmat.2016.02.085.

27. Demirboga (2007) "Thermal Conductivity and Compressive Strength of Concrete Incorporation with Mineral Admixtures" Building and Environment 42: 2467-71. https://doi.org/10.1016/j.buildenv.2006.06.010 
28. Dubey, S., Singh, A. and Kushwah,S.S. (2019) "Utilization of Iron and Steel Slag in Building Construction, " AIP Conference Proceedings. https://doi. org/10.1063/1.5127156

29. Zhang, Z., Zhang,B., and Yan,P. (2016) "Comparative Study of Effect of Raw and Densified Silica Fume in the Paste , Mortar and Concrete." CONSTRUCTION \& BUILDING MATERIALS 105: 82-93. https://doi.org/10.1016/j.conbuildmat.2015.12.045

30. Huang, C. and. Feldman, R.F. (1985) "Influence of Silica Fume on the Microstructural Development in Cement Mortars,"Cement and Concrete Research 15 (2): 285-94. https://doi.org/10.1016/00088846(85)90040-7

31. Imam, A., Kumar,V., and Srivastava,V. (2018) "Review Study towards Effect of Silica Fume on the Fresh and Hardened Properties of Concrete" Advances in Concrete Construction2: 145-57. https:// doi.org/10.12989/acc.2018.6.2.145

32. Douaissia, Z., and Merzoud,M. (2019)“Effect of Slag and Natural Pozzolan on the Mechanical Behavior of Recycled Glass Mortars," Computational Methods and Experimental Testing In Mechanical Engineering. Springer International Publishing. https://doi. org/10.1007/978-3-030-11827-3

33. Rao, G A.(2003)“Investigations on the Performance of Silica Fume-Incorporated Cement Pastes and Mortars," Cement and Concrete Research33:1765-70. https://doi.org/10.1016/S0008-8846(03)00171-6

34. Singh, H., and Bansal,S.( 2015) "EFFECT OF SILICA FUME ON THE STRENGTH OF CEMENT MORTAR," International Journal of Research in Engineering and Technology623-27.

35. Chouhan, P., Jamle,S., and Verma,M.P.( 2017) "Effect of Silica Fume on Strength Parameters OfConcrete As A Partial Substitution of Cement" IJSART3 (5): 3-7.

36. ASTM C778 (2013). Standard Specification for Standard Sand. Annual book of ASTM Standards.

37. ASTM C1437 (2013). Standard Test Method for Flow of Hydraulic Cement Mortar. Annual book of ASTM Standards.

38. ASTM C642 (2013). Standard Test Method for Density, Absorption, and Voids in Hardened Concrete. Annual book of ASTM Standards.

39. ASTM C567 (2013). Standard Test Method for Ultrasonic Pulse Velocity Test of Concrete". Annual book of ASTM Standards.
40. ASTM C109 (2013). Standard Test Method for Compressive Strength of Hydraulic Cement Mortars (Using 2-in. or [50-mm] Cube Specimens). Annual book of ASTM Standards.

41. ASTM C348 (2014). Standard Test Method for Flexural Strength of Hydraulic-Cement Mortars. Annual book of ASTM Standards.

42. Al-zubaid,A.B, Muttar,K., Ali,I. (2017) "Study The Effect of Recycled Glass on The Mechanical Properties of Green Concrete" Energy Procedia 119: 680-92. https://doi.org/10.1016/j.egypro.2017.07.095

43. Worrell, E., Price,L., Martin,N., Hendriks,C., and Meida,L.O.. (2001) "CARBON DIOXIDE EMISSIONS FROM THE GLOBAL CEMENT INDUSTRY" Annu. Rev. Energy Environ 26:303-329. https://www. annualreviews .org

44. Queiroz, W. D., Carlos,J., Rubens,J., and Camargo,D. (2013) "Waste Materials Co-Processing in Cement Industry: Ecological Efficiency of Waste Reuse." Renewable and Sustainable Energy Reviews 19: 200-207. https://doi.org/10.1016/j. rser.2012.11.01

45. Taylor, M., Tam,C., and Gielen,D. (2006) "Energy Efficiency and $\mathrm{CO}_{2}$ Emissions from the Global Cement Industry," Energy Technology Policy Division, International Energy Agency. September: 4-5.

46. World Bank. (2019) "Trends in Solid Waste Management"The World Bank Group ,available at http:// datatopics.worldbank.org/what-a waste/trends_in_ solid_waste_management.html.

47. Myers, R. H. (1990) "Classical and modern regression with applications (2nd ed.).Boston. Pws-Kent Publishing Company.

48. Djordjevi, V. (2002) "Testing in Multiple Regression Analysis" FACTA UNIVERSITATIS ,Series: Economics and Organization 1: 25-29.

49. Zsuzsanna, T. and Marian,L. (2012) "Multiple Regression Analysis of Performance Indicators in the Ceramic Industry." Procedia - Social and Behavioral Sciences 3 (12): 509-14. https://doi.org/10.1016/ S2212-5671(12)00188-8.

50. Joshi, R., Banwet,D.K. and Shankar,R.. (2011) "Expert Systems with Applications A Delphi-AHP-TOPSIS Based Benchmarking Framework for Performance Improvement of a Cold Chain." Expert Systems With Applications 38 (8): 10170-82. https:// doi.org/10.1016/j.eswa.2011.02.072 
51. Russo, R. D.F.S M, and Camanho,R. (2015) "Criteria in AHP : A Systematic Review of Literature.” Procedia - Procedia Computer Science 55 (Itqm): 112332. https://doi.org/10.1016/j.procs.2015.07.081.

52. Saaty, T. L. (1990) "How to Make a Decision: The Analytic Hierarchy Process" European Journal of Operational Research 48:9-26.
53. Kutlu, A. C. (2012) "Fuzzy Failure Modes and Effects Analysis by Using Fuzzy TOPSIS-Based Fuzzy AHP" Expert Systems with Applications .39: 61-67. https://doi.org/10.1016/j.eswa.2011.06.044

54. Snellings, R., Mertens, G., and Elsen,J. (2012) "Supplementary Cementitious Materials" Reviews in Mineralogy \& Geochemistry74 (Blezard 2001): 211-78. https://doi.org/10.2138/rmg.2012.74.6. 